\title{
THE REFUSE ACT OF 1899: ITS SCOPE AND ROLE IN CONTROL OF WATER POLLUTION
}

Recently, the Department of the Interior filed civil complaints against mercury polluters under an obscure section of the Rivers and Harbors Act of 1899. Little is known of the history of "the Refuse Act" or of its applicability to the modern problem of water pollution. This Comment attempts to define the scope of the Act through examination of its legislative, judicial and administrative history and furthermore, explores possible modes of action and remedies available under it. The author feels that use of the Refuse Act as a complement to existing federal water quality legislation, essentially embodied in the Water Quality Act of 1965, will contribute to attainment of the goal of comprehensive and effective control of water pollution.

Water is our most precious resource. Essential to all life-c"synonymous" with life, as one Congressman put it ${ }^{1}$-water is also indispensable to many imdustrial and recreational activities associated with advanced civilization. Perhaps because their continent is generously endowed with fresh water supphes, ${ }^{2}$ Americans have been profligate with their seemingly imexhaustible fortune. ${ }^{3}$ In this century, careless consumption of water and wholesale deposit of wastes into waterways have assumed enormous proportions, turning rivers and lakes into open sewers. The result: fish kills of substantial proportions, ${ }^{4}$ bans on commercial fishing, ${ }^{5}$ closing of recreational areas, ${ }^{8}$ and, occasionally, a scarcity of usable water. ${ }^{7}$ It has been predicted that at the present rate of population growth Americans will be using their water resources to capacity by $1980 .^{8}$ Whether or not that projection is accurate, there is

1. J. Wright, The Coming Water Famine 5 (1963).

2. R. RIENOW \& L. RIENOW, MOMENT IN THE SUN 69 (1965). One-fourth of the water contained in the earth's fresh-water lakes and seas is found in North America. Id.

3. According to the Department of the Interior, in 1965, Americans used 359 billion gallons of water a day which amounted to approximately 1,900 gallons per capitn per day for all uses. Id. at 70 .

4. See J. Wright, supra note 1, at 35; G. Berg, Water Poliution 14-16 (1970).

5. For example, on March 24, 1970, the Canadian Government banned commercial fishing in Lake St. Clair, and the St. Clair and Detroit Rivers, due to mercury contamination. Ohio and Michigan also restricted fishing because of the possibility of mercury poisoning, Ohio including Lake Erie in its ban. See 1 BNA ENVIRONMENT REP.CURRENT 30 (1970) [hereinafter cited as ENVIR. REP.-CURRENT].

6. For example, since 1959 Milwaukee's four beaches on Lake Michigan havo been closed intermittently due to excessive pollution. Hill, The Great and Dirty Lakes, SATURDAY REVIEW, Oct. 23, 1965, at 33.

7. See J. Wright, supra note 1, at 21; Lear, What Brought It On?, SATURdnY REvIEw, Oct. 23, 1965, at 24 (New York drought).

8. See R. RIENOW \& L. RIENOW, supra note 2, at 72; J. WRIGHT, supra note 1 , at 19-20. 
widespread recognition that the problem is critical. At stake may be not only personal freedom as we know it today-for severe water shortage will bring regimentation ${ }^{9}$ - but also the existence of civilization itself. ${ }^{10}$ A refusal to be destroyed by our own wastes entails a rejection of the philosophy that man must conquer nature and the substitution of efforts to strike a bargain with her ${ }^{11}$ or make good his debt ${ }^{12}$ incurred over the years of exploitation.

The preliminary step is to halt the despoliation of our waters; the difficult question is: by what means? The first conceivable weapon is the common law rule permitting riparian owners reasonable use of water and providing the complementary right to use of water which is free of unreasonable pollution. But that device was incapable of solving the problems of water contamination even in the relatively simple, agrarian society in which it originated. Courts even then avoided the difficult balancing necessary to determine a standard of reasonableness. ${ }^{13}$ The extent of the current problem deinonstrates the madequacy of the common law approach.

The Refuse Act, ${ }^{14}$ section 13 of the Rivers and Harbors Act of

9. Inhabitants of some parts of the world, such as Hong Kong, have experienced water rationing. See R. RIENOW \& L. RIENow, supra note 2, at 72.

10. See generally id. at 37-38. Plato wrote of "[t]he shrines [of decayed civilizations] that survive to the present day on the sites of extinct water supplies . . . . J. WRIGHT, supra note 1 , at 94.

11. Lear, supra note 7 , at 80.

12. State of the Union Message by President Richard M. Nixon, 1970 U.S. CODE CONG. \& ADMTN. NEWS 11.

13. Note, Water Quality Standards in Private Nuisance Actions, 79 Yale L.J. 102-06 (1969). The Note suggests that the standards formulated under the Water Quahity Act [33 U.S.C. $\$ \$ 466-66 n$ (Supp. V, 1970), as amended, Water Quality Improvement Act of 1970, Pub. L. No. 91-224, 84 Stat. 91 (to be codified as 33 U.S.C. $\$ \S 1151-75)]$ may provide the courts with an opportunity to achieve uniformity, the lack of which rendered the "reasonable use" test an ineffective weapon against water pollution. However, the legislative history of the Act indicates that Congress did not intend the water quality standards to be given conclusive effect in a private action: "[I]t is not the standards themselves but abatement orders considered with such standards which are enforcible." S. RzP. No. 10, 89th Cong., 1st Sess. 10 (1965). Still, the courts may voluntarily accept the standards as a very important fact in the determination of reasonable use; an effective use of the standards would be for a court to rule that a prima facie case is established by showing a violation. Reference to the standards would replace the determination of the reasonableness of defendant's use of water in terms of industrial practice with that of the reasonableness of his use in terms of comprehensive allocation of water rights among legitimate users. Note, supra at 108-09.

14. 33 U.S.C. $\$ 407$ (1964):

It shall not be lawful to throw, discharge, or deposit, or cause, suffer, or procure to be thrown, discharged, or deposited either from or out of any ship, barge, or other floating craft of any kind, or from the shore, wharf, manufacturing establishment, or mill of any kind, any refuse matter of any kind or description whatever other than that flowing from streets and sewers and passing therefrom in a liquid state, into any navigable water of the United States, or into any tributary of any navigable water from which the same shall float or be washed into such navigable water and it shall not be lawful 
1899 , is another potential instrument. In the last year, the government has filed several civil complaints under it to combat pollution, ${ }^{15}$ a use of the Act that has provoked considerable controversy. The statute, however, provides no procedure for formulation of water quahty standards, giving the Chief of the Army Corps of Engineers discretion in the issuance of permits to discharge refuse into navigable waterways. Although action by the Corps would be an expedient method of preventing further degradation of waters, in the past the Corps has not used the permit authority to discourage pollution. ${ }^{16}$ Given the enormity of the problem and the range of interests affected, more comprehensive legislation could provide the most effective approach to cleaning up our waters.

The Federal Water Pollution Control Act (FWPCA), ${ }^{17}$ as amended, is an attempt to apply this approach. Unfortunately, the statute, with its cumbersome enforcenent procedure has not had the desired effect. ${ }^{18}$ President Nixon impliedly recognized the inability of the Act in its present form to substantially achieve the goal of pure wa-

to deposit, or cause, suffer, or procure to be deposited material of any kind in any place on the bank of any navigable water, or on the bank of any tributary of any navigable water, where the same shall be liable to be washed into such navigable water, either by ordinary or high tides, or by storms or floods, or otherwise, whereby navigation shall or may be impeded or obstructed: provided, That nothing herein contained shall extend to, apply to, or prohibit the operations in connection with the improvenent of navigable waters or construction of public works, considered necessary and proper by the United States officers supervising such improvement or public work: and provided further, That the Secretary of the Army, whenever in the judgment of the Chief of Engineers anchorage and navigation will not be injured thereby, may permit the deposit of any material above mentioned in navigable waters, within limits to be defined and under conditions to be prescribed by him, provided application is made to lim1 prior to depositing such material; and whenever any permit is so granted the conditions thereof shall be strictly complied with and any violation thereof shall be unlawful.

15. Suits were authorized against the following firms: Georgia-Pacific Corporation, Bellinghain, Wash.; Olin Corporation, Niagara Falls, N.Y.; Oxford Paper Company, Rumford, Maine; Weyerhaeuser Coinpany, Longview, Wash.; Olin Corporation, Augusta, Ga.; Diamond Shamrock Corporation, Delaware City, Del.; Diamond Shamrock Corporation, Muscle Shoals, Ala.; Allied Cheinical Company, Solvay, N.Y.; International Mining and Chemical Company, Chlor-Alkali Division, Orrington, Maine; Pennwalt Chemical Company, Calvert City, Ky. EnvIR. ReP.-CURRENT 349. Several of these companies have settled with the government by limiting the amount of mercury discharged daily. See id. at 607,655 .

16. The Refuse Act has been virtually ignored. For example, as of November 20 , 1970, there were no permits outstanding for discharge of refuse into San Francisco Bay. Interview with an unidentified representative, Army Corps of Engineers, in San Francisco, November 1970. (The representative did not wish to be quoted by name.)

17. 33 U.S.C. $\$ \$ 466-66 n$ (Supp. V, 1970), as amended, Water Quality Inprovement Act of 1970, Pub. L. No. 91-224, 84 Stat. 91 (to be codified as 33 U.S.C. $\S$ 1151-75).

18. See Barry, The Evolution of the Enforcement Provisions of the Federal Water Pollution Control Act: A Study of the Difficulties in Developing Effective Legislation, 68 Mich. L. Rev. 1103 (1970). 
ter when he suggested promulgation of comprehensive new regulations to meet the continuing challenge. ${ }^{19}$

While neither the Refuse Act nor the FWPCA offers a solution to the water crisis, a combination of the two statutes corrects some of the deficiencies in each. This Comment will analyze each law with respect to its scope, manner of enforcement, and application to environmental protection and finally, will demonstrate how relating one act to the other may enhance the effectiveness of federal water quality control.

THE REFUSE ACT

\section{A. Scope of the Act}

\section{Federal Authority Over "Navigable Waters"}

Under the commerce clause, Congress has the power "to regulate commerce . . . among the several States . . .,"20 to which end it may enact all laws "necessary and proper."21 "Commerce" comprehends navigation and the word "regulate" implies full power over the thing to be regulated, a power which may be exercised to its utmost extent. ${ }^{22}$ Hence, the commerce power encompasses not only control of navigation per se but also the regulation of activities which affect navigable waters. "Navigability" has been defined as follows: "Those . . . rivers .. . which are navigable in fact. And they are navigable in fact when they are used, or are susceptible of being used, in their ordinary condition, as highways for commerce . . .."23 However, federal jurisdiction over the non-navigable upper reaches and tributaries of waterways has also been sustained in order to protect navigability downstream. ${ }^{24}$ Furthermore, in determining navigability, the Supreme Court has found it proper to consider for jurisdictional purposes a waterway's prospects for use after reasonable improvements have been made, although such improvements might not be completed or even authorized at the time of suit. ${ }^{25}$

Thus, as an exercise of the congressional power to protect navigability, the Refuse Act is no longer open to serious attack; rather its applicability has increased with the broadening of the definition of "navigable." Courts have repeatedly upheld section 13 and closely related

19. State of the Union Message, supra note 12 , at 7, 11 .

20. U.S. CoNST. art. I, \& 8 (3).

21. Id. $\$ 8$ (18).

22. Gibbons v. Ogden, 22 U.S. 1, 92, 9 Wheat. 1, 209 (1824).

23. The Daniel Ball, 77 U.S. (10 Wall.) 557, 563 (1870).

24. United States v. Rio Grande Dam \& Irrig. Co., 174 U.S. 690, 707-10 (1898).

25. United States v. Appalachfan Elec. Power Co., 311 U.S. 377, $407-08$ (1940). 
sections as proper exercises of legislative authority to prevent obstruction, impediment and injury to navigable waters. Prohibition of dumping of dredged material is within congressional authority under the commerce clause; ${ }^{26}$ regulation of waste disposal in harbors to protect waterways from obstruction and injurious deposits is a valid exercise of federal police power; ${ }^{2 \tau}$ restrictions imposed to protect the navigability of streams are binding on the states; ${ }^{28}$ and jurisdiction over obstructions to navigable streams within the United States is vested solely in the federal government. ${ }^{29}$ The further extension of section 13 to control modern industrial pollutants will be discussed in a subsequent section. ${ }^{80}$

\section{Statutory Construction: The Meaning of "Refuse"}

If the Refuse Act is to be an effective weapon in the federal antipollution arsenal, "refuse" must be interpreted liberally. Fortunately, the courts have been continually broadening its reach. An understanding of the legislative history of the Act and its subsequent judicial construction are necessary to analyze the suitability of the use of the statute for controlling pollution of the waterways.

The predecessor of the Refuse Act was section $6^{31}$ of the Rivers and Harbors Act of $1890 .{ }^{32}$ Congress passed the 1890 Act in response to the United States Supreme Court's decision that a direct statute was necessary to bring obstructions and nuisances in navigable rivers within the scope of federal judicial review since there was no common law of the United States which controlled them. ${ }^{33}$ Section 6 of the Act prohibited the casting, throwing, emptying, or unlading of specific substances-ballast, stone, slate, gravel, rubbish, sawdust-and of "refuse, or other wastes of any kind" into ports, roads, or navigable waters unless a permit was first secured from the Secretary of War. ${ }^{34}$

26. 22 OP. ATT'Y GEN. 646, 653 (1899).

27. United States v. Romard, 89 F. 156, 159 (2d Cir. 1898).

28. Amory v. Commonwealth, 321 Mass. 240, 248, 72 N.E.2d 549, 555 (1947). See also Bowes v. City of Chicago, 3 Ill. 2d 175, 120 N.E.2d 15 (1954).

29. The Fort Fetterman v. South Carolina Highway Dep't., 261 F.2d 563, 565 (4th Cir. 1958).

30. See pt. I, $B$ infra.

31. Rivers and Harbors Act of 1890, ch. 907, § 6, 26 Stat. 453.

32. Ch. 907, §§ 1-18, 26 Stat. 426. Intervening between the 1890 and 1899 Rivers and Harbors Acts was the Rivers and Harbors Act of 1894, ch. 299, §§ 1-13, 28 Stat. 338. Section 6 of that Act read in part:

It shall not be lawful to place, discharge, or deposit, by any process or in any nıanner, ballast, refuse, dirt, ashes, cinders, nud, sand, dredgings, sludge, acid, or any other matter of any kind other than that flowing from streets, sewers, and passing therefrom in a liquid state, in the waters of any harbor or river of the United States ....

Id. $\$ 6,28$ Stat. 363 .

33. Williamette Iron Bridge Co. v. Hatch, 125 U.S. 1, 8 (1888).

34. Rivers and Harbors Act of 1890, ch. 907, § 6, 26 Stat. 453. 
Although there was considerable evidence of injury to navigable waters from discharges of various substances, ${ }^{35}$ the Senate debate over section $6^{36}$ was much less vigorous ${ }^{37}$ than the discussion of section $7,{ }^{38}$ which was eventually superceded by section $10^{39}$ of the Rivers and Harbors Act of $1899,{ }^{40}$ concerning the creation of structural obstructions to the navigable capacity of waters. The courts' subsequent struggle to define refuse in the absence of legislative guidance mirrored the legislature's preoccupation with physical obstructions to navigation.

In accord with the legislative concern that waters be free of obstruction, the cases prosecuted under section 13 usually involved deposits of matter which threatened to impede navigation. Correspondingly, courts have generally perceived the purpose of the Act in terms of obstruction: "these statutes [are] to prevent the discharge of matter which will clog or obstruct the harbor or other navigable waters." ${ }^{\text {1 }}$ But in 1936 the Ninth Circuit departed from the traditional

35. Injury to navigable waters from sawmill wastes, booms for logs, deposits of ballast, ashes, oysters and rubbish was substantiated by the Chief of Engineers. H.R. REP. No. 2760, 50th Cong., 1st Sess. 2 (1887); S. REP. No. 224, 50th Cong., 1st Sess. 2 (1887).

36. See 21 Cong. Rec. 1319 (1890).

37. See id. at $8587,8678$.

38. Ch. 907, § 7, 26 Stat. 454.

39. Ch. $425, \S 10,30$ Stat. 1151 (codified at 33 U.S.C. $\$ 403$ (1964)):

[T] he creation of any obstruction not affirmatively authorized by Congress, to the navigable capacity of any of the waters of the Umited States is prohibited; and it shall not be lawful to build or commence the building of any wharf, pier, dolphin, boom, weir, breakwater, bulkhead, jetty, or other structures in any port, roadstead, haven, harbor, canal, navigable river, or other water of the United States, outside established harbor lines, or where no harbor lines have been established, except on plans recommended by the Chief of Engineers and authorized by the Secretary of the Army; and it shall not be lawful to excavate or fill, or in any inanner to alter or modify the course, location, condition, or capacity of, any port, roadstead, haven, harbor, canal, lake, harbor of refuge, or inclosure within the limits of any breakwater, or of the channel of any navigable water of the United States, unless the work has been recommended by the Chief of Engineers and authorized by the Secretary of the Army prior to beginning the same.

Section 10 has historically had wider and more significant use than section 13 . See notes 62-67, 89-95 infra and accompanying text.

40. Congress, atteinpting to consolidate all laws relating to maintenance, protection and preservation of navigable waters, enacted the Rivers and Harbors Act of 1899 whicb, according to its advocates, was a compilation containing only "very shight changes to remove ambiguities." 32 CONG. REC. 2297 (1899) (remarks of Senator Frye). Agam, the Congressional Record shows no significant discussion pertaining to deposit of refuse in navigable waters.

41. Nicroli v. Den Norske Afrika-Og Australienie, 332 F.2d 651, 655 (2d Cir. 1964). Yet, at least one case states that the statute's "plain purpose is to protect navigable waters from pollution and shoaling through the prohibited conduct." Perry v. Sanfield, 278 Mass. 563, 570, 180 N.E. 514, 516 (1932). The fact situation in that case is a singular one, though, and has no relevance to industrial pollution. Plaintiff's intestate was dumping garbage from a boat when a schooner collided with it. The court held that the illegal element in the conduct of the intestate was not a contributing cause to his injuries. 
characterization. In La Merced, ${ }^{42}$ which presented the issue of whether oil was refuse within the meaning of the Act, the court saw no reason for limiting refuse to such matter as would impede or obstruct navigation. ${ }^{43}$

The next obstacle to interpretation was the question of whether the discharge of valuable, usable oil constituted a throwing, discharging or depositing of refuse matter. Despite the construction of "refuse" in La Merced, the federal district court in United States $v$. The Delvalle ${ }^{44}$ read refuse in the adjective sense of "[r]efused, rejected; thrown aside or left as worthless or of no value; worthless, useless"45 and held that it did not include oil. Nevertheless, a later case in the Second Circuit, United States v. Ballard Oil Co., ${ }^{46}$ took the opposite position, holding that "refuse" did not demand that materials be deliberately discarded. It was enough that something had become a waste in the water, however useful it may earlier have been. ${ }^{47}$

In addition, the court in Ballard followed La Merced's statutory construction by holding that refuse included substances which did not physically impede navigation. However, Ballard, like La Merced, concerned oil spillage, an occurrence creating a fire hazard. Thus, danger to navigation may have been the basis of the opinion, although the

42. 84 F.2d 444 (9th Cir. 1936). Two cases had reached the same result under a similar statute, 33 U.S.C. $\& 449$ (1964), which prohibits dumping of certain wastes into the Harbor of New York. The Albania, 30 F.2d 727 (S.D.N.Y. 1928), held that "[o]il upon the surface of harbor is quite as dangerous to shipping as the pollution of its waters with acid, and it would defeat the obvious purpose of the statute to so narrowly construe its language as to exclude from its prohibition the discharge of waste fuel oil." Id. at 728. The reasoning in The Colombo, 42 F.2d 211 (2d Cir. 1930) was similar: "[W] most certainly for this reason that oil was not specifically included, for in recent years this has become a great nuisance and a serious danger to the harbor.” Id. at 212. Dcspite these precedents, the Army Corps of Engineers had not anticipated the applicability of the Refuse Act to oil. In a letter supporting the Oil Pollution Control Act of 1924, the Chief of Engineers wrote: "The use of the words 'impeded or obstructed' imply a physical hindrance to navigation which does not occur in the case of oil. It is therefore unlikely that the courts would hold that oil . . . is refuse matter coming within the scope of the prohibition contained in law." S. REP. No. 66, 68th Cong., 1st Sess. 2 (1922). The Chief of Engineers implied later, however, that enforceinent rather than applicability of the Act to liquid pollutants constituted the problem:

The essential purpose of the Act of March 3,1899, was to prevent the introduction into navigable waters of such material as would form a physical obstruction to navigation. It has proven reasonably effective in preventing the discharge of such materials. . . . In practice it has been found impracticable to control under this law any form of hquid pollution even though it comes from a source other than streets and sewers.

H.R. Doc. No. 417, 69th Cong., 1st Sess. 19-20 (1926).

43. 84 F.2d at 446 .

44. 45 F. Supp. 746 (E.D. La. 1942).

45. Id. at 748 .

46. 195 F.2d 369 (2d Cir. 1952).

47. Id. at 371 . 
actual holding may be read as supporting a much broader proposition. The Ballard court saw the statute as delineating two separate offenses. The first-to cause any refuse matter to be discharged into navigable water of the United States-is unqualified. The second-to cause matter of any kind to be deposited in any place on the bank of any navigable river where it would be liable to be washed into navigable water-is modified by the phrase "whereby navigation shall or may be impeded or obstructed." 48

In a 1966 opinion, United States v. Standard Oil Co.,${ }^{49}$ the Supreme Court adopted the Ballard interpretation on both issues, holding that section 13 covered the discharge of commercially valuable aviation gasoline. .00 "Oil is oil," wrote Justice Douglas, "and whether usable or not by industrial standards it has the same deleterious effect on waterways. In either case, its presence in the rivers and harbors is both a menace to navigation and a pollutant." ${ }^{1}$ Refuse, simply a catch-all term, includes all foreign substances other than wastes flowing froni streets and sewers im a liquid state, which are specifically excluded from the operation of section 13 .

The Court's broad construction of "refuse" in Standard Oil was entirely consistent with its earlier interpretation, in United States $v$. Republic Steel Corp., ${ }^{52}$ of the exception of "wastes in a liquid state." There, in a case involving both section 13 and section 10 , a shoaling condition was created by discharge of industrial solids in suspension. The Court ruled that the deposit of such industrial waste in a liquid state did not fall within the exception since refuse flowing from "sewers" in a "liquid state" meant "sewage." "53

Thus, the courts have developed a fairly liberal construction of the Refuse Act. Refuse is matter of any kind, whether or not commercially valuable; and, with the exception of liquid flowing from streets and sewers, a discharge without a permit of such refuse into a navigable waterway is prohibited. Substances in suspension, substances whicl pre-

48. Id. at 370 ; see note 14 supra.

49. 384 U.S. 224 (1966).

50. The Court based its decision on an analogy of section 13 to its predecessors. First, the prior sections drew no distinction on their faces between valuable and valueless substances. Second, of the substances enumerated, some may well have been of commercial and industrial value before discharge into the navigable waterways. Third, those acts applied not only to the enumerated substances but also to the discharge of any other matter of any kind and since the enumerated substances included those with a pre-discharge value, the rule of ejusdem generis does not require limitation of the general category to substances lacking in predischarge value. Fourth, the coverage of superseded sections was not diminished by the codification of 1899 . Id. at 228 .

51. Id. at 226 (emphasis added).

52. 362 U.S. 482 (1960).

53. Id. at 490 . 
cipitate or flocculate into larger units and are deposited in the river bottom, do not come within the exception. Rather, since they obstruct navigation, they are subject to both sections 10 and 13 . However, it is not necessary that refuse impede navigation to be regulated, although prohibition may depend on whether or not the material represents some type of danger to navigation. In arriving at this position, the courts have abandoned the more limited statutory purpose suggested by legislative history and early precedent of protecting navigation from physical obstruction. ${ }^{54}$ In addition, modern courts seem inclined to allow the Corps of Engineers wide jurisdiction in exercising its permit authority. ${ }^{55}$ So, although there are no reported cases under section 13 concerning discharge of chemical imdustrial pollutants other than oil or gasoline, the rule that has evolved apparently will be broad enough to reach such practices.

\section{B. Enforcement}

Under the Refuse Act the Secretary of the Arnny may permit deposit of materials in navigable waters if, in the judginent of the Chief of Engineers, anchorage and navigation will not be injured thereby. ${ }^{50}$ The permits are to prescribe limits and conditions, any violation of which is unlawful. The Corps of Engineers has the administrative tasks of issuing permits and of policing conduct under them. While the Corps has the authority to set criteria governing issuance of permits to discharge, the section provides no guidance concerning factors to be considered in setting the standards.

The courts are the ultimate enforcers of the Refuse Act. A broad construction of the Act, however, raises the question of judicial competence to set standards of water quality. With the continuing absence of specific statutory standards, a court faced with defendant's lack of a discharge permit lias a choice between enjoming the "illegal" discharge

54. Many factors indicate the narrow purpose of protection of navigation from physical obstruction. Section 13 was associated with other measures dealing with sunken wrecks [33 U.S.C. $\$ 409$ (1964)], construction of bridges and piers [id. $\$ 401]$, and injury to public works sites [id. $\$ 408]$. Furthermore, while there was an awareness of the hazards of pollution to the general health and welfare of the nation [see, e.g., Annot., 38 A.L.R. 321 (1904); The Disposal of Sewage and Pollution of Rivers, 68 J.P. 51, 87 (1904) (treatment of sewage); River Pollution by Sewage, 63 J.P. 450 (1899) (contamination by sewage and chemical refuse)], there was no discussion of the problem in relation to the Act. See notes 37-39 supra and accompanying text. Finally, the coinmonly accepted meaning of refuse is "trash," "garbage." See United Statcs v. Standard Oil Co., 384 U.S. 224, 230-37 (1966) (Harlan, J., dissenting).

55. The Refuse Act must not be given a "narrow, cramped reading" but must be read "charitably in the light of the purpose to be served." United States v. Republic Steel Corp., 362 U.S. 482, 491 (1960). "We cannot construe section 13 in a vacuum," wrote Justice Douglas in United States v. Standard Oil Co., 384 U.S. 224, 226 (1966), referring to the crisis of pollution.

56. See note 14 supra. 
and applying its own standard of reasonableness to defendant's conduct. ${ }^{57}$ Under the second alternative, the law would revert to the old rule of reasonable use which, presumably, would be as ineffective today as it was in the past. ${ }^{68}$ If the Refuse Act is to become a significant tool for water regulation, the Corps, not the courts, is the appropriate source of standards specific enough to insure uniformity of judicial review.

Historically, rather than proinulgate its own standards, the Corps has tended to defer to the objectives of local pollution control programs in determining whether to grant waste disposal permits. ${ }^{59}$ Prior to the revisions of the Corps' regulations effective January 1970, the Corps' permit jurisdiction under sections 10 and 13 was limited to that control necessary to protect navigation from obstructive and injurious materials. ${ }^{60}$ Moreover, in the area of policing, the Corps rehed primarily on friendly persuasion, recommending prosecution only in cases of flagrant violation. ${ }^{61}$

The January 1970 regulations, while maintaining the pohicy of securimg coinpliance administratively and resorting to prosecution only in cases of willful and intentional violation, indicate the Corps' intention to assune a wider jurisdiction under section 10 by emphasizng considerations not purely navigational. The decision to issue a permit

57. Sinee the Corps of Engineers has not used the Refuse Act to control pollution, there are few permits outstanding. See note 16 supra and accompanying text. A spokesman for the Corps in San Francisco estimated that it will take two years after the new regulations [see note 68 infra and accompanying text] become effective to determine the permit status of all parties discharging matter into San Francisco Bay. Interview, supra note 16. In the interim, the courts, ill-equipped to make technical judgments, must decide whether to enjoin discharge. The injunction, which may have serious effects on a great number of people, will not be supported by the preliminary administrative consideration envisaged by the Refuse Act.

On the other hand, a specific refusal by the Corps, supported by proper proceedings, presents a different question and gives courts the guidance necessary to make an effective ruling. In view of the goals of the political system of the United States, however, it would be disturbing if the Refuse Act became the major weapon against pollution, since the Corps is not an elected body and, while the Congress of 1899 was, it is no longer representative of the public. Thus, the better approach demands that the Act be used in conjunction with the standards of the Water Quality Act of 1965.

58. See note 13 supra and accompanying text.

59. 33 C.F.R. $\$ 209.330,209.395$ (1967).

60. Id. \& 209.395.

61. [I]t lias long been standing policy to secure compliance with . . . provisions short of legal proceedings. Prosecution was recommended only in cases of willful or intentional violation. It was the Corps' established policy not to recommend prosecution when the violation was "trivial, apparently unpremeditated, and [resulted] in no material public imjury" or when the violation was "minor, unintentional, or accidental, and the party responsible [made] good the damages suffered.

Id. \$ 209.400. See also United States v. Republic Steel Corp., 362 U.S. 482 (1960), and, for background to that case, see generally H.R. Doc. No. 494, 72d Cong., $2 \mathrm{~d}$ Sess. (1932). 
must now rest on "an evaluation of all relevant factors, including the effect of the proposed work on navigation, fish and wildlife, conservation, pollution, aesthetics, ecology and the general public interest." Provision is made for coordination of applications for permits with the Regional Director of the Fish and Wildlife Service whenever a body of water would be controlled or modified as the result of the proposed improvement. Moreover, in recognition of the responsibilities of all federal agencies to improve water quality, ${ }^{03}$ the regulations imdicate the Corps' intention to cooperate with the Secretary of the Interior and other state and interstate agencies and municipalities preventing or controlling water pollution. State regulations will be considered guidelines until federal standards are prescribed; ${ }^{34}$ permits will contain the condition that the permittee comply with all regulations issued in the future by the Federal Water Pollution Control Administration or the state water pollution control agency having jurisdiction to abate or prevent water pollution. ${ }^{65}$

An explanation of enforceinent of the Refuse Act, found later in the regulations does not show an expansion of considerations in issuing permits under section 13 corresponding to that under section 10 . The only criterion mentioned is that the deposit must not be injurious and, while the district engineer is apprised of his duty to "take notice of any violations of the laws for the protection of the navigable waters", ${ }^{60}$ there is no provision for hearings on permit standards, the violation of which is the district engineers' concern. As indicated by case law, injurious deposits would definitely include deposits of petroleun products and deposits of solids in suspension which accumulate, creating obstructions to navigation. ${ }^{67}$ The regulations leave open the question of whether the deposit must be deleterious to navigation or create a substantial hazard thereto or whether "injurious" is used in an absolute sense.

Perhaps in response to the need to set a standard for determination of what deposits are injurious, the Department of the Army has pro-

62. 33 C.F.R. $\$ 209.120$ (d)(1) (1970).

63. Memorandum of Understanding Between the Secretary of the Interior and the Secretary of the Army, reprinted at 33 C.F.R. $\$ 209.120$ (1970), referring to Executive Order No. 11288, 3 C.F.R. ch. IV (1966), which states that "The heads of the departments, agencies, and establishments of the Executive Branch of the Government shall provide leadership in the nationwide effort to improve water quality through prevention, control, and abatement of water pollution from Federal Government activities in the United States."

64. 33 C.F.R. $\S 209.120$ (d)(8) (1970).

65. Id. The procedural sections also concern permits under section 10 referring to "civil works programs" and "proposed work," but not to unrelated deposits of refuse. If public interest warrants one, a public hearing is to bo held where all interested parties may make their views known. Id. $\$ 209.120(\mathrm{~g})$.

66. Id. $\$ 209.170(\mathrm{~g})(3)$.

67. See notes $42-53$ supra and accompanying text. 
posed new regulations for the issuance of permits under the Refuse Act. ${ }^{68}$ Coordination of the anti-pollution effort is the underlying policy of the rules. While anchorage and navigation are still pertinent considerations, authorization will be based in part on an evaluation of the effect of the discharge on water quality standards under the Federal Water Pollution Control Act and on fish and wildlife resources, under the aegis of the Fish and Wildlife Coordination Act, ${ }^{69}$ which are not directly related to water quality standards. ${ }^{70}$ The regulations, recognizing that the inajor responsibility for water quality resides in the relevant state and federal agencies, cast the Regional Representatives of the Environinental Protection Agency ${ }^{71}$ in an advisory role to the District Engineers. ${ }^{72}$ Absent objections by the Regional Representatives, the engineers may deny a permit in three situations only: Where anchorage or navigation will be impaired; where, after consultations required by the Fish and Wildlife Coordination Act, the District Engineer determines that the discharge will adversely affect fish or wildlife resources; where issuance or denial of a permit would be imconsistent with the purposes of the Refuse Act. ${ }^{73}$ However, no permit nay be issued to an apphicant who has been denied certification by the appropriate agency under section $21(b)(1)$ of the FWPCA. ${ }^{74}$ Hence, while requiring at a ninimum coinpliance with water quality standards under the FWPCA, the regulations retain sufficient flexibility to prohibit discharges not covered thereby.

The proposals specify that applicants must describe in detail the character of the effluent-chemical content, water temperature differentials, toxins, sewage, alnount and frequency of discharge or deposit

68. Proposed Army Reg. $§ 209.131,35$ Fed. Reg. 20005 (1970).

69. 16 U.S.C. \& 661 (1964).

70. Proposed Army Reg. \$ 209.131(d)(2), 35 Fed. Reg. 20005 (1970).

71. See 35 Fed. Reg. 15623 (1970). Pursuant to section 2 of Reorganization Plan No. 3 of 1970, all functions vested in the Secretary of the Interior by the FWPCA were transferred to the newly-created EPA. Id.

72. Proposed Army Reg. $\$ 209.131$ (d) (3), 35 Fed. Reg. 20005 (1970).

73. Id. \$209.131(d)(5), 35 Fed. Reg. 20005.

74. Id. $\$ 209.131$ (d)(7), 35 Fed. Reg. 20005. See also id. $\$ 209.131(\mathrm{~h}), 35$ Fed. Reg. 20005. Section 21(b) (1) reads in part:

Any applicant for a Federal hcense or permit to conduct any activity including, but not limited to, the construction or operation of facilities, which may result in any discharge into the navigable waters of the United States, shall provide the licensing or permitting agency a certification from the State in which the discharge originates or will originate, or, if appropriate, from the interstate waterpollution control agency having jurisdiction over the navigable waters at the point where the discharge originates or will originate, that there is reasonable assurance, as determined by the State or interstate agency that such activity will be conducted in a manner which will not violate applicable water quality standards....

Water Quality Improvement Act of 1970, Pub. L. No. 91-224, 84 Stat. 91 (to be codified as 33 U.S.C. $\$ \$ 1171(b)(1))$. 
and the type and quantity of solids involved. ${ }^{75}$ Upon completion of applications, notices containing information concerning the proposed discharge inust be posted in public places and sent to a variety of interested parties ${ }^{76}$ who are to be given reasonable time-not less than 30 days-to express their views. ${ }^{77}$ Public hearings will be held whenever there is a manifestation of substantial public interest or whenever federal, state or local authorities so request. ${ }^{78}$ Thus, the public is given more information and greater opportunity to exert influence than under the former regulations.

While the authority of the Corps to set general pollution regulations under the statute is not establisled, courts might uphold the new regulations on any one of three possible grounds: First, although the Refuse Act states that the criterion for granting permits is that ancliorage and navigation will not be hanned by the particular discharge, the language is permissive rather than mandatory. If, $m$ the opinion of the Chief of Engineers, anchorage and navigation will not be imjured, the Secretary of the Army may permit the deposit of inaterial. He is not required to do so, even though there is no danger of mjury. Second, some waters, notably Lake Erie, are "dying" prematurely due to excessive deposits of pollutants. ${ }^{79}$ In view of this fact, one may argue that standards of cliemical purity are necessary to prevent the nation's lakes and rivers from becoming swamps and, therefore, are essential to protection of navigation. Fimally, the Fifth Circuit ${ }^{80}$ has held that in granting permits under the Rivers and Harbors Act the Corps is not restricted to consideration of factors affecting navigation. Basing its decision in part on the declaration of the National Environmental Policy Act of $1969^{81}$ that every federal agency shall consider ecological factors when dealing with activities which may have an impact on the environment, the court ruled that the Corps had the power under section 10 to refuse a request for a permit to fill a part of Boca Ciega Bay on the grounds that the proposed fill would have a detriniental effect on fish and wildlife resources. ${ }^{82}$ By analogy, the Corps has the authority to deny permits under section 13 for ecological reasons.

The question of the Corps' authority to set standards may arise but rarely, however. Although the wording of the sections 10 and 13

75. Proposed Army Reg. \$ 209.131(g), 35 Fed. Reg. 20005 (1970).

76. Id. \$§ 209.131(i)(5), (j)(1), 35 Fed. Reg. 20005.

77. Id. $\S 209.131(\mathrm{j})(1), 35$ Fed. Reg. 20005.

78. Id. $\S \S 209.131$ (i)(6), (k)(1), 35 Fed. Reg. 20005.

79. See T. Aylesworth, This Vital Air, This Vital Water 112 (1968); G. Bero, supra note 4, at 17-18; R. RIENOW \& L. ReINOW, supra note 2, at 94-95; Hill, supra note 6 , at 33 .

80. Zabel v. Tabb, 430 F.2d 199 (5th Cir. 1970).

81. 42 U.S.C. $\$ 4331$ (Supp. V, 1970).

82. 430 F.2d at 214. 
indicates a greater concern for water quality in areas of life unrelated or related but tangentially to navigation, the underlying policy of the regulations, deference to opinions of other governmental bodies on standards relating to pollution ${ }^{83}$ remains the same. The regulations pertaining to both sections 10 and 13 defer to state and federal water quality agencies on questions of water pollution. It is evident that, since an elaborate scheme for determining standards has been established under the 1965 amendments to the Federal Water Pollution Control Act, the Water Quality Act of $1965,{ }^{84}$ and under various state statutes, ${ }^{85}$ the Corps will rely leavily upon the expertise of agencies created by those enactments im setting permit standards. Hence, the Corps of Engineers will, through its authority under the Refuse Act, contribute to enforcement of the Water Quality Act.

\section{Remedies}

If the Refuse Act is to have a significant impact on water quality, suitable standards nust govern issuance of permits and violators must be brought to court. The Corps of Engineers, with its opportunities for policmg activities of dischargers, has the primary responsibility for seeking judicial enforcement of the Act. Other governmental agencies, however, may participate ${ }^{86}$ and several theories support standing of private parties to challenge discharges violative of the Act.

\section{Governmental Action}

Section 13 is a criminal statute, the violation of which carries the penalty prescribed in section $16 .^{87}$ Thus, the normal remedy under

83. See notes $59 \& 63-65$ supra and accompanying text.

84. 33 U.S.C. $\$ 466 \mathrm{~g}$ (Supp. V, 1970), as amended, Water Quality Improvement Act of 1970, Pub. L. No. 91-224, § 112, 84 Stat. 114 (to be codified as 33 U.S.C. $\$ 1160$ ).

85. See, e.g., CAL. WATER CODE $\$ \S 13000-951$ (West Supp. 1971).

86. The defendant in United States v. Interlake Steel Corp., 297 F. Supp. 912 (N.D. Ill. 1969), moved to dismiss the action on the grounds that the prosecution was not undertaken at the request of the Secretary of the Army, U.S. Corps of Army Engineers, or any other officer authorized to do so under the Rivers and Harbors Act of 1899. The conrt followed United States v. Burns, 54 F. 351 (C.C.W. Va. 1893), which held that, despite the statutory authorizatiou, "the right and duty of the district attorney and of the grand jury to initiate proceedings in the manner usual to criminal cases, is not affected and it remains as heretofore." Id. at 355. In Interlake the information leading to prosecution was provided by the Coast Guard. See also United States v. Esso, 375 F.2d 621

(3d Cir. 1967).

87. 33 U.S.C. $\$ 411$ (1964). Section 16 reads in part:

Every person and every corporation that shall violate, or that shall knowingly aid, abet, anthorize, or instigate a violation of the provision of [section 13], shall be guilty of a misdemeanor, and on conviction thereof shall be punished by a fine not exceeding $\$ 2,500$ nor less than $\$ 500$, or by iniprisonment . . not less than thirty days, nor inore than one year, or by both such fine and iniprisonment.... 
the statute, as in the case of other crimes, is in the hands of the government and, accordingly, under section $17,{ }^{88}$ the Department of Justice has the responsibility for litigation. It is questionable, however, whether the criminal penalties are sufficient to accomplish the Act's purpose. Even if construed as per diein penalties, the specified fines are too low to be effective since the cost of pollution control devices or completely new facilities would in many cases far exceed the total fine. There are, lowever, precedents for equitable remedies.

Despite the general rule that penal statutes be construed narrowly, courts have held that an action by the government for an injunction is proper under section 10. In United States $v$. Republic Steel Corp. ${ }^{80}$ the Supreme Court granted the government imjunctive relief. Justice Douglas construed section 17, providing that the Department of Justice conduct the "legal proceedings necessary to enforce" the Rivers and Harbors Act, to mean that detailed codes which provide for every contingency are not necessary. "Congress has legislated and made its purpose clear; it has provided enough federal law in section 10 from which appropriate remedies may be fashioned even though they rest on inferences. Otherwise we impute to Congress a futility inconsistent with the great design of this legislation." the United States has an interest to protect or defend. That imterest, which the mjunction will serve, is defined by the sections of the Act. ${ }^{01}$

Other courts have also fashioned remedies not specifically provided in the Act. An early case ${ }^{02}$ held that acquittal of the defendant imdicted under section $12^{03}$ for creating an obstruction in violation of section 10 was not a bar to a subsequent suit in equity brought by the United States under the same section against the defendant to compel the removal of such obstruction. ${ }^{04}$ Recently, Judge Friendly of the Second Circuit held that the United States could recover damages in the amount expended in the dredging of a canal to remove an obstruction caused by the defendant. ${ }^{.5}$

Although there are no similar cases dealing with the breadth of the courts' power to formulate remedies for violations of the Refuse Act, presumably, the courts' power would be the same under it as under section 10. Since the governmental interest expressed by the Refuse Act is in prevention of obstruction to navigation and, conceivably, control of

88. Id. § 413 .

89. 362 U.S. 482 (1960).

90. Id. at 492 .

91. Id.

92. United States v. Donaldson-Shultz Co., 148 F. 581 (C.C.E.D. Va. 1906).

93. 33 U.S.C. § 406 (1964).

94. $148 \mathrm{~F}$. at 585 .

95. United States v. Perma Paving Co., 332 F.2d 754 (2d Cir. 1964). 
general chemical pollution of waters, under the reasoning of Republic Steel injunctive or other expedient relief would be proper to accoinplisli either purpose.

\section{Private Redress}

Although some courts have demed a private right of action under the Refuse Act, ${ }^{96}$ since the prevailing tendency is to expand its scope, private litigants might now meet with less resistance. Private suits may be based on two theories-qui tam and tort.

A qui tam action is a suit brought under a statute that establishes a penalty for the commission or omission of a certain act and gives the penalty, in whole or im part, to anyone who sues for it. The plaintiff describes himself as suing for himself as well as for the government. ${ }^{97}$ Qui tam statutes have existed for hundreds of years in England and in this country since its colonization. ${ }^{98}$ While sucli actions have been viewed with disfavor by some courts, others have defended them on the ground that they afford an inexpensive and effective means of enforcing the statute. ${ }^{99}$ The issue, however, of whether section 13 creates a genuine qui tam action is unsettled. ${ }^{100}$ Moreover, the reaction of contemporary courts to this common law concept of standing is a matter of conjecture.

96. See, e.g., H. Christiansen \& Sons, Inc. v. City of Duluth, 154 F.2d 205 (8th Cir. 1946), involving damage to a dock caused by timbers beating against it. The court ruled that because section 13 is penal in nature, it should be narrowly construed and, further, since it contains no provision for the recovery of damages for its violation, it does not establish civil liability. Rather, it imposes a penalty for wrong to the public. "Any private right of action which exists under it is by imphication only and would not in any event extend beyond the purpose of its prohibition." Id. at 207. Christiansen held further that the purpose of the statute was the protection of navigation; the dock which was damaged pertained to the land and, since there was neither allegation nor proof that navigation was impeded or obstructed, the plaintiff had no right to damages under section 13. Other cases have held that obstruction to navigation is an essential element of a complaint under section 13. In Longstean v. Owen McCafrey's Sons, 95 Conn. 486, 111 A. 788 (1920), the court did not allow damages for injury to plaintiff's cottage by defendant's barge because a statute "does not give a cause of actionable neghigence in favor of private individuals unless the statute was designed to prevent such injuries as were suffered by the individual claiming damage and unless it imposes upon the one violating the statute a specific duty for the protection and benefit of him who claims damage for the violation." Id. at $493-94,111 \mathrm{~A}$. at 792 . The statute here protects navigation, not cottages on the shore.

97. United States v. Griswold, 24 F. 361 (D. Ore. 1885).

98. Marvin v. Tront, 199 U.S. 212, 225 (1905).

99. United States v. Griswold, 24 F. 361 (D. Ore. 1885).

100. See generally Conservation and Natural Resources Subcomm. of the Comm. on Government Operations, 91st Cong., 24 Sess., Qu TAM Actions aNd the 1899 Refuse Act: Cittzen Lawsutts Against Polluters of the Nation's WaTERWAYs (Comm. Print 1970) thereinafter cited as QUI TAM ACTIONS AND THE 1899 REPUSE ACT]. 
Section 16 of the Rivers and Harbors Act of $1899^{101}$ provides that "one-half of said fine . . . be paid to the person or persons giving information which shall lead to conviction." Although the section makes no mention of the right of the informer to sue, and although section 17 states that it is the duty of the United States Attorneys to prosecute all offenders, a recent House of Representatives report has noted that "where a statute provides for a reward to the informer, the statute authorizes him, if the government has not previously initiated a prosecution against the violator, to institute his own suit in the name of the United States (a qui tam action) to collect his noiety of the penalty."102 As authority for this assertion, the report quotes United States ex rel. Marcus v. Hess, ${ }^{103}$ a Supreine Court case citing Adams, qui tam v. Woods ${ }^{104}$ as support for the proposition that "statutes providing for reward to informers which do not specifically either authorize or forbid the informer to institute the action are construed to authorize him to sue."105 Adams however, dealt not with the specific subject of qui tam suits, but with the application of a statute of limitations to civil and criminal actions. ${ }^{106}$ In dicta the Court noted that: "Almost every fine or forfeiture under a penal statute, nnay be recovered by an action of debt, as well as by information. . . . In this particular case, the statute which creates the forfeiture does not prescribe the mode of demanding it; consequently, either debt or information would lie."107 Thereafter, Chief Justice Marshall held that the statute of limitations barred either type of action. It is not clear that Hess correctly interpreted the Adams dicta. The statute in Adams provided that one-half of the fine recovered would be paid "to the use of him or her who shall sue for and prosecute the same."108 So although the statute did not "prescribe the mode of demanding" the forfeiture, it did explicitly give private persons

101. 33 U.S.C. § 411 (1964).

102. H.R. REP. No. 917, 91st Cong., 2d Sess. 17 (1970).

103. 317 U.S. 537 (1943).

104. 6 U.S. 335, 2 Cranch 336 (1804).

105. United States ex rel. Marcus v. Hess, 317 U.S. 537, 541 n.4 (1943).

106. In Adams, the plaintiff brought an action of debt under a federal act which prohibited slave trade from the United States to any other country, providing that the violator "forfeit and pay the sum of two thousand dollars; one moiety thereof to the use of the United States, and the other moiety thereof to the use of him or her who shall sue for and prosecute the same." 6 U.S. at 335, 2 Cranch at 336 . The plaintiff contended that the statute of limitations was no bar to an action of debt-a civil processsimce it applied only to criminal proceedings or, alternatively, if it were a bar, the statute only applied to the recovery of penalties imposed by acts which existed at the time of its passage. Marshall, C.J., rejected both contentions, holding that the action was barred by the statute and that the "words of the act of Congress plainly applied to all finds and forfeitures under any penal act, whenever that act niight pass." Id. at 341, 2 Cranch at 342 .

107. Id. at 341,2 Cranch at 341.

108. Id. at 335,2 Cranch at 336. 
the right to prosecute under it. In contrast, section 17 of the Rivers and Harbors Act of 1899 imposes an apparently exclusive duty on the Department of Justice to carry out the litigation necessary to enforce the Act. ${ }^{109}$

Later cases have not clarified qui tam requirements. Citing a statute which implicitly recognized the right of an informer to sue, ${ }^{110}$ United States $v$. Payne ${ }^{111}$ stated that " $[t]$ he prosecution may be instituted by an informer, and thus ... become[s] a qui tam action."112 Yet, another court ${ }^{113}$ wrote, like Hess, that "[a]ny words of a statute which show that a part of the penalty named therein shall be for the use of an informer will entitle him to maintain an action therefor if he complies with the conditions of the statute."114

A rather musty and dusty common law relic, qui tam is not quite understood and perhaps not valued by modern courts. In 1898 a court could say: "At one time informers performed an important part in the collection of the penalties provided in penal statutes, but . . . they .. . lave now about disappeared in penal litigation."115 Section 13 was passed a generation after the last previous qui tam statute which is still a part of the United States Code ${ }^{116}$ and there is no evidence suggesting that the legislature intended the Refuse Act to be enforced by qui tam proceedings. Thus, there are substantial doubts concerning the basis of a qui tam action in section 13. Due to the present reluctance of the Justice Department to perform its duty, ${ }^{117}$ interpretation of the section as authorizing qui tam actions may be justified as a means of enforcing the statute. This mode of proceeding, however, seems alien to modern procedural and judicial concepts, which favor enforcement of criminal sanctions by the state rather than by individuals.

A better basis for private action sounds in tort and depends on a determination that the activity prohibited by the Refuse Act constitutes

109. 33 U.S.C. $\$ 413$ (1964).

110. 25 U.S.C. $\$ 201$ (1964) gives "one-half [of the penalty] to the use of the informer and the other half to the use of the United States, except when the prosecution shall be first instituted on behalf of the United States . . . ."

111. 22 F. 426 (D.C. Kan. 1884).

112. Id. at 427 (einphasis added).

113. United States v. Stocking, 87 F. 857 (D.C. Mont. 1898).

114. Id. at 861 .

115. Id. at 862 .

116. 31 U.S.C. $\$ \$ 231-33$ (1964) (originally enacted as Act of Mar. 2, 1863, ch. $67, \S \S 1,3,12$ Stat. 698). Other statutes still in force which give the informer a part of the fine are the following: 31 U.S.C. $\$ \$ 155,163,1003$ (1964) (originally enacted as Act of Sept. 2, 1789, ch. 12, § 8, 1 Stat. 67); 46 U.S.C. $\$ \S 1351-56$ (1964) (originally enacted as Act of Mar. 22, 1794, ch. 11, 1 Stat. 347); 25 U.S.C. \$ 201 (1964) (originally enacted as Act of June 30,1834, ch. 161, § 27, 4 Stat. 733). See QUI TAM ACTIONS AND THE 1899 REFUSE ACT 3-4 for repealed informer statutes.

117. See notes 198 \& 199 infra and accompanying text. 
a nuisance. ${ }^{118}$ Roughly defined, a common law public nuisance is an act or ommission whicl1 obstructs or causes inconvenience or dainage to the public in the exercise of rights common to all. ${ }^{110}$ The term includes offenses based on soine interference with an interest of the commumitypublic health, safety, morals, peace, comfort, convenience. ${ }^{120}$ It is not necessary that the entire community be affected, so long as the nuisance will interfere witl those who come in contact with it. ${ }^{121}$ For example, the obstruction of a public highway which inconveniences only those who travel upon it is a public nuisance. ${ }^{122}$ Similar characterization of obstruction of a navigable waterway follows easily. Thus, since prevention of impediments to navigation was the original purpose of the Refuse Act, ${ }^{123}$ it is arguable that Congress intended the statute to define a nuisance.

Generally, the community interest with regard to the public nuisance must be vindicated by appointed representatives. ${ }^{124}$ The reason given for this rule is the danger of multiplicity of suits were private individuals allowed to sue in the name of pubhe right. ${ }^{125}$ If, however, a plaintiff can show that he lias suffered special damage, damage distinguishable froin that sustained by the general coinmunity, he may sue personally in tort. ${ }^{126}$ While the question of what constitutes special damage has not been settled, ${ }^{127}$ it is likely that anyone who has incurred actual or pecuniary dannage has a basis for suit. ${ }^{128}$ Hence, if the Refuse Act is characterized as a nuisance statute, a private right of action under it may be imphed. Kelly v. Leheigh Navigation Coal Co. ${ }^{120}$ supports this conclusion. The Third Circuit overruled a demurrer to plaintiff's action for damages; defendant's duniping of coal wastes into the river in violation of section 13 had allegedly caused the bed of the river to rise, making it impossible for vessels to be brought close enough to shore to unload thein at plaintiff's wharf. The court reinarked that, in the case of an award, dainages should be predicated, not on the extent of monetary loss or damage sustained, but on the value of the right to be protected, which for Kelly was the right to occupy and enjoy its property and to function as a business organization. ${ }^{130}$

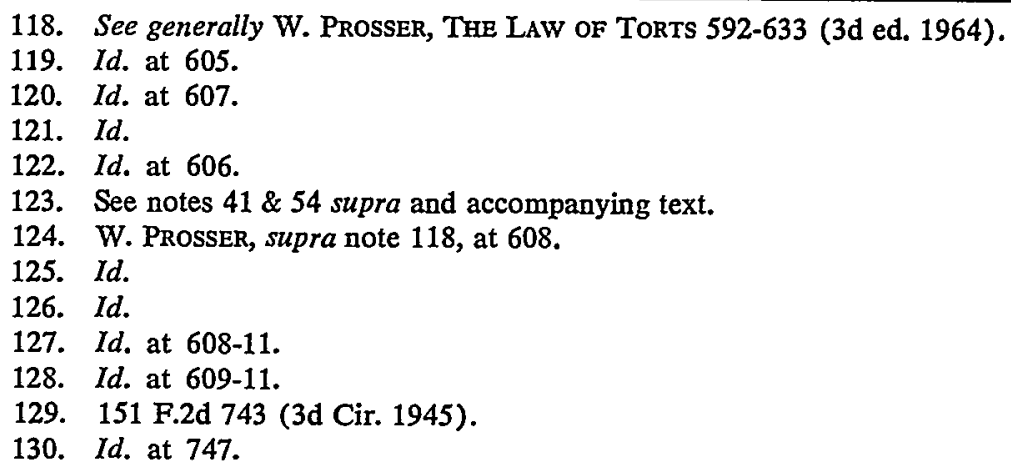


In addition to standing granted those suffering special damage, one nay sue on a theory of private nuisance based on unwarranted or unlawful use of property that caused injury, damage, hurt, inconvenience, annoyance or discomfort to plaintiff in the legitimate enjoyment of his reasonable rights of property. ${ }^{131}$ Most private nuisance litigation has concerned conflicting interests of landowners and the reasonableness of the conduct challenged. ${ }^{132}$ The difficulty involved, is, of course, the determination of "reasonable use"-striking a balance between the social value of a person's activity and its result, which may be detrimental to the rights of other individuals. Generally, if an action is designated by a statute as a public nuisance, inquiry into its unreasonable character will be unnecessary. ${ }^{133}$ Thus, apparently, a consideration of "reasonableness" is not essential to determining liability in tort for a violation of section 13.134 Compliance would not, however, insulate a party against an action for nuisance. There is dicta to the effect that, although a permit from the Department of the Army to discharge waste into a river may be a valid defense to criminal prosecution under the Refuse Act, such authority does not carry with it the right to create a private nuisance. ${ }^{135}$ In the case of a discharge legal under section 13, liability to a private party must be predicated on some standard other than that by whicli the permits are issued. The courts would have difficulty in setting that standard by themselves. ${ }^{136}$

Although substantial uncertainty and confusion surrounds the law of nuisance, ${ }^{137}$ its general framework supports the accommodation of private actions under the Refuse Act in situations where special damage results from public nuisance, or if private nuisance occurs. Moreover, rule $23^{138}$ of the Federal Rules of Civil Procedure, providing for class actions, may elininate the necessity for one party's bearing the expense of litigation.

The purpose of rule 23 is to establish a means of adjudicating disputes where it is inpractical or impossible for all interested parties to appear before the court. Moreover, the rule attempts to provide protection from inultiple litigation and a method for obtaining redress for in-

131. Maier v. Publicker Comm. Alcohol Co., 62 F. Supp. 161, 165 (E.D. Pa. 1945).

132. See generally W. PROSSER, supra note 118, at 613-23.

133. See id. at 597. "[M]any ... nuisances are marked out by statute, and it is not necessary for the court to look further than the legislative declaration that the conduct is a criminal offense."

134. Id. at 604.

135. Maier v. Publicker Comm. Alcohol Co., 62 F. Supp. 161, 165 (E.D. Pa. 1945). Contra, Slingerland v. International Contracting Co., 43 App. Div. 215, 60 N.Y.S. 12 (1899).

136. See note 13 supra and accompanyimg text.

137. W. Prosser, supra note 118, at 592-94.

138. FED. R. CIV. P. 23. 
juries which would otherwise be too small to warrant individual suits. ${ }^{139}$ The need for a device allowing combination of parties in the latter situation resulted primarily from progressive separation of roles in society, distribution of goods and services on a wide scale, and astronomical costs of litigation. ${ }^{400}$ Thus, rule 23 has been utilized in actions involving the claims of shareholders, ${ }^{141}$ especially in relation to alleged misrepresentation under Securities and Exchange Commission rule $10 \mathrm{~b}-5 ;{ }^{142}$ infringements of civil rights; ${ }^{143}$ proceedings in habeas corpus; $;^{144}$ violations of antitrust laws; ${ }^{145}$ and use of tax revenues. ${ }^{140}$ There are, however, no recorded cases in which citizens have maintained class actions against violators of the Refuse Act.

Although members of the class suing a polluter may easily be so numerous that joinder of all members is impracticable, ${ }^{147}$ numbers alone do not establish a class. The individuals comprismg the group must prossess a right which determmes their relation to other members ${ }^{148}$ and to their common adversary. ${ }^{149}$ In the case of violations which constitute a public nuisance without special damage, an action brought by representatives of the general public would probably not pass muster under rule 23. The public's interest in clean water relates to health, recreation and aesthetics. The interests represented in a class action would not be specific enough to distinguish any group from the public in general and thus satisfy the prerequisites of a class under the rule. In addition, representation and notice problems might present serious constitutional questions. On the other hand, violation of the Refuse Act which results

139. Eisen v. Carlisle \& Jacquelin, 391 F.2d 55 (2d Cir. 1968).

140. Modern society seems increasingly to expose men to such group injuries for which they are in a poor position individually to seek legal redrcss, either because they do not know enough or because such redress is disproportionately expensive. If each is left to assert his rights alone if and when he can, there will at best be a random and fragmentary enforcement, if there is any at all. This result is not only unfortunate in the particular case, but it will operate seriously to impair the deterrent effect of the sanctions which underlie much contemporary law. The problem of fashioning an effective and inclusive group remedy is . . . a major one.

Kalvan \& Rosenfeld, The Contemporary Function of the Class Suit, 8 U. CHI. L. REv. 684,686 (1941).

141. See, e.g., Eisen v. Charlisle \& Jacquelin, 391 F.2d 555 (2d Cir. 1968); Demarco v. Edens, 390 F.2d 836 (2d Cir. 1968).

142. 17 C.F.R. $\$ 240.10 \mathrm{~b}-5$ (1970); see, e.g., Hohman v. Packard Instrument Co., 399 F.2d 711 (7th Cir. 1968); Green v. Wolf Corp., 406 F.2d 291 (2d Cir. 1968); Fischer v. Kletz, 41 F.R.D. 377 (S.D.N.Y. 1966).

143. See, e.g., Norwalk CORE v. Norwalk Dev. Agency, 395 F.2d 920 (2d Cir. 1968); Potts v. Flax, 313 F.2d 284 (5th Cir. 1963).

144. Adderly v. Wainwright, 272 F. Supp. 530 (M.D. Fla. 1967).

145. Siegel v. Chicken Delight, Inc., 271 F. Supp. 722 (N.D. Cal. 1967).

146. Booth v. General Dynamics Corp., 264 F. Supp. 465 (N.D. Ill. 1967).

147. FeD. R. CIV. P. 23(a)(1).

148. Id. $23(\mathrm{a})(2)-(3)$.

149. Id. 23(b). 
in special damage or the creation of a private nuisance could be the foundation for a well-defined class right. A class of persons-such as commercial fishermen whose business is suffering and businessmen whose waterfront became unacceptable to tourists because of excessive pollution-who can claim special damage or the existence of a private nuisance would fulfill the requirements of rule 23 . Furthermore, the general purpose of rule 23-to afford a mode of obtaining redress to large groups of people for whoin the expense of hitigation would otherwise be prohibitive-and the precedent for liberal construction ${ }^{150}$ may lead courts to allow such actions despite the uncertainties of defining a private right under the Refuse Act.

Hence, while there is no recent authority for private actions under the Refuse Act, and qui tam actions under it have not been tested in the courts, neither of these theories is precluded as a basis for suits by private parties. Moreover, since the purpose of the statute has broadened beyond the simple protection of navigation to include many other goals such as preservation of fish and wildlife, recreation, or the needs and welfare of the people, and since recent Supreme Court decisions reflect a concern for water quality, courts may look favorably on private actions designed to accomplish ecologically desirable results.

II

THE WATER QUALITY ACT OF 1965

\section{A. Standards Procedure}

Prior to 1965, federal legislation for water pollution control, the Federal Water Pollution Control Act and subsequent amendinents, reflected the view that pollution was a local problem, to be solved priinarily by state governments and inunicipalities. ${ }^{151}$ The 1965 anendments which comprise the Water Quality Act, however, were hailed as separate and new developments of paramount importance. ${ }^{152}$ Section (1)(a) departed from the concepts of the older legislation by defining the purpose of the Act as the enhancenent of "the quality and value of our water resources"153 and the establishment of "a national policy for

150. "[D]ismissal in limine of a particular proceeding as not a proper class action is justified only by a clear showing to that effect and after a proper appraisal of all factors enumerated on the face of the rule itself." Eisen v. Carlisle \& Jacquelin, 391 F.2d 555, 563 (2d Cir. 1968). "[A]ny error, if there is to be one, should be commited in favor of allowing the class action." Esplin v. Hirschi, 402 F.2d 94, 101 (10th Cir. 1968).

151. See Barry, supra note 18, at 1104-14.

152. H.R. REP. No. 215, 89th Coug., 1st Sess. 1-2 (1965).

153. 33 U.S.C. $\$ 466$ (Supp. V, 1970), as amended, Water Quality Improvemeut Act of 1970, Pub. L. No. 91-224, § 102, 84 Stat. 91 (to be codified as 33 U.S.C. § 1151). 
the prevention, control and abatement of water pollution."154 Notwithstanding these declarations, sections of the former law recognizing and preserving state jurisdiction over waters ${ }^{\mathbf{1 5 5}}$ and encouraging state and interstate action to abate pollution ${ }^{156}$ were retained. Thus, authority to curb pollution was confused rather than clarified.

Despite the conflicting implications of the Act, section 10 (c) (1) ${ }^{157}$ gives the Administrator of the Environmental Protection Agency -originally the Secretary of the Interior-final authority to establish water quality standards. The state may, on its own initiative, adopt water criteria "consistent" with the Act and establish plans for their implementation and enforcement. State water criteria and plans are subject to acceptance by the Administrator. ${ }^{158}$ If the state fails to adopt its own criteria, the Administrator may prepare regulations setting forth federal standards of water quality to be applicable to the state's interstate waters or portions thereof. ${ }^{159}$ Standards prepared by the Administrator are to be reviewed by a hearing board composed of five or more of its appointees, and, in addition, one person selected at the option of each state that would be affected by such standards. ${ }^{100}$ If the hearing board approves of the Administrator's standards, they become effective upon receipt by the Administrator of the board's ruling. ${ }^{101}$ If the board advises modification of the standards, the Administrator must revise them in accordance with the board's recommendations. ${ }^{162}$ The revised standards become effective immediately upon promulgation. There is no mention of the availability of judicial review of the hearing board's determination.

There is some dispute over the type of regulations the Administrator is authorized to issue. ${ }^{163}$ The differing interpretations are due to the

154. 33 U.S.C. $\$ 466$ (Supp. V, 1970).

155. Id. $\$ 466 \mathrm{~b}$.

156. $I d . \$ 466 \mathrm{~g}(\mathrm{~b})$.

157. Id. $\$ 466 \mathrm{~g}(\mathrm{c})(1)$. See note 71 supra for transfer of functions under the FWPCA from the Department of the Interior to the Environmental Protection Agency.

158. 33 U.S.C. $\$ 466 \mathrm{~g}$ (c) (2) (Supp. V, 1970).

159. Interstate, as defined in section 13(e), means "all rivers, lakes and other waters that flow across or form a part of state boundaries, including coastal waters." Hearings on Water Pollution Before the House Comm. on Public Works, 90th Cong., 1st Sess. 88 (1967). For an analysis of the limitations of the Act's jurisdiction and the constitutional implications involved, see Bermingliam, The Federal Government and Air and Water Pollution, 23 Bus. Law. 467 (1968); Dunkelberger, The Federal Government's Role in Regulating Water Pollution under the Water Quality Act of 1965, 3 NATURAL Res. LAW. 3 (1970); Edelman, Federal Air and Water Control: The Application of the Commerce Power to Abate Interstate and Intrastate Pollution, 33 GEO. Wash. L. REv. 1067 (1965).

160. 33 U.S.C. $\$ 466 \mathrm{~g}$ (c) (4) (Supp. V, 1970).

161. Id.

162. Id.

163. See generally Dunkelberger, Federal-State Relationships in the Adoption of 
complexity and ambiguity of the relationship between the state and federal governments under the Act. Under section 10(c)(1), the state water quality criteria - or in lieu thereof, the standards established by the Administrator-applicable to "interstate waters or portions thereof within sucll State"164 must take local peculiarities into considerationdifferences in water supplies, fisl and wildlife, agricultural and industrial uses. ${ }^{165}$ Although the Administrator's judgment may supplant that of the state, the legislative history suggests a rejection of national stream and effluent standards. ${ }^{160}$ As a result of a compromise between House of Representatives advocates of local regulation and Senate proponents of national standards, federal standards are to be adopted under section 10 (c) (2) only if state standards are not, in the view of the Administrator, consistent with the Act. ${ }^{167}$ To aid in determining what criteria will be consistent with the Act, the Department of the Interior establislied "guidelines"108 for the states. Two of these guidelines liave come under special attack: guideline $8,{ }^{169}$ requiring secondary treatment of discharges; and guideline $1,{ }^{170}$ setting the policy of non-

Water Quality Standards Under the Federal Pollution Control Act, 2 NaTuRal Res. LAw. 47 (1969).

164. 33 U.S.C. $\$ 466 \mathrm{~g}(\mathrm{c})(1)$ (Supp. V, 1970).

165. Id. $\$ 466 \mathrm{~g}(\mathrm{c})(3)$.

166. See Dunkelberger, supra note 159 . The campaign for national water quality standards, led by Senator Muskie, began in 1963 with the introduction of S.649, a bill to amend the Federal Water Pollution Control Act which provided for federal water quality standards apphicable to the quality of receiving water and the quality of the effluent. The bill, amended to eliminate authority for the adoption of effluent standards and to provide for federal standards only in the event of a state failure to promulgate standards consistent with the Act, passed the Senate but the Public Work's Committee rejected the mandatory water quality standards provision, modifying the bill to provide for "recommendation" of criteria by the Secretary. H.R. REP. No. 1885, 88th Cong., 2d Sess. 7 (1964). The 88th Congress adjourned before the House had acted definitively.

In the 89th Congress, the Senate passed S.4, which contained a section relating to water quality standards identical to that of S.649; the provision was eliminated in the version of the bill passed by the House. See H.R. REP. No. 215, 89th Cong., 1st Sess. $3,8,9$ (1965). Sent to conference, the bill emerged containing a water quality standards provision similar to that of the Senate's.

167. 33 U.S.C. $\$ 466 \mathrm{~g}(\mathrm{c})$ (1) (Supp. V, 1970).

168. See Hearings on Water Pollution Before the House Comm. on Public Works, 90th Cong., 1st Sess. 86-88 (1967).

169. Guideline 8:

No standard will be approved which allows any waste amenable to treatment or control to be discharged into any interstate water without treatment or control regardless of the water quality criteria and water use or uses adopted. Further, no standard will be approved which does not require all wastes, prior to discharge into any interstate water, to receive the best practicable treatment or control unless it can be demonstrated that lesser degree of treatment or control will provide for water quality and enhancement commensurate with proposed present and future water uses.

Id. at 88 (emphasis added).

170. Guideline 1:

Water quality standards should be designed to enhance the quality of water. 
degradation of waters. Some commentators have argued that guideline 8 requires a national effluent standard of the type opposed by Congress. ${ }^{171}$ Opponents argue that the guideline clearly refers to the treatment of the discharge, rather than to the water quality criteria apphicable to the receiving stream. Since seetion 10(c)(5) refers to discharges which reduce the "quality of such waters below the water quality standards established under this section,"172 the standards applicable are stream standards and not discharge standards. Therefore, opponents contend that under the Water Quality Act state water quality criteria need not include a secondary treatment requirement to be consistent with the Act. ${ }^{173}$ In the case of the non-degradation requirement of guideline one, the argument has been made that, in promulgating stream standards under section $10(\mathrm{c})(3),{ }^{174}$ the use and value of the particular body of water for various purposes must be taken into consideration. The possibility of reduction of water quality in the stream must be weighed against the importance to the state of a particular use of the waters. Thus, within some limits, a state is free to permit degradation of water in order that the stream may be used for a purpose of importance to the state. ${ }^{175}$

These disputes illustrate that, although the water quality standards provisions enhance in some way federal authority in the area of water pollution control, they do not adequately define the federal role. Yet, it is probable that the administrators-and the courts in the last resort-will favor federal determination of standards, rather than state, for several reasons. First, the states have been incapable of controlling pollution in the past. Second, local governmental units may be more susceptible than the federal government to pressures from local industries. Third, smce pollution control is expensive, the states may be tempted to lure inajor industry into their jurisdiction with the promise of lower water quality standards and correspondingly lower operating costs. Finally, the financial limitations on local and state governments providing facilities and research and the duplication of effort which would result froin such fragmented control efforts make it likely that the federal government will occupy the field in the future. Given the technological complexity of regulation in the area of pollution control and

If it is impossible to provide for prompt improvement in water quality at the time imitial standards are set, the standards should be designed to prevent any increase in pollution. In no case will standards providing for less than existing water quality be acceptable.

Id. at 87.

171. See Dunkelberger, supra note 163 , at 55.

172. 33 U.S.C. $\$ 466 \mathrm{~g}$ (c)(5) (Supp. V, 1970).

173. Dunkelberger, supra note 163 , at 55 .

174. 33 U.S.C. $\& 466 \mathrm{~g}(\mathrm{c})$ (3) (Supp. V, 1970).

175. Dunkelberger, supra note 163 , at 55 . 
the many individual variations for which an agency must account, it is probable that the federal standard will become a minimum standard which the states may embellish to meet local needs.

\section{B. Enforcement Procedure}

The general enforcement procedure involves conference, hearing and judicial review. The Administrator is empowered to call a conference of relevant agencies: at the request of governor of a state, the state water pollution control agency, or the governing body of any municipality, on the grounds that pollution of the waters is endangering the health and welfare of persons in a state other than that in which the discharge originates; at the request of the governor of a state if danger exists only with respect to persons within the state in which the pollutant originates; whenever, on the basis of reports, surveys, or studies, he has reason to believe that pollution of interstate or navigable waters endangers the health or welfare of persons in a state other than that in which the discharge occurs or results in substantial economic mjury from the inability to market shellfish or shellfish products in interstate commerce. ${ }^{176}$

The statute gives little guidance concerning conference procedure. The agencies called to attend the conference may bring such persons as they desire and interested parties are permitted to make statements and file reports. ${ }^{177}$ After conclusion of the conference, the Administrator may make recommendations to the proper agency to take remedial action. Upon establishment of a reinedial schedule, the states are encouraged to obtain compliance under their own authority and are allowed at least six months to take action. Where local agency cooperation is good, a favorite technique of the federal agency has been to schedule conferences in series to periodically re-examine the progress that is being made in remedying the problem under surveillance. ${ }^{178}$

In the case of failure to take remedial action within the time allotted, the Administrator may call a public hearing. ${ }^{179}$ If the hearing board finds that such pollution is occurring and effective progress toward its abatement is not being made, it is to make recommendations to the Administrator concerning measures to secure abatement. ${ }^{180}$ The recommendations are forwarded to the violators, together with a notice specifying a reasonable time in which to secure abatement of such pollution. ${ }^{181}$

176. 33 U.S.C. $\& 466 \mathrm{~g}(\mathrm{~d})(1)$ (Supp. V, 1970).

177. Id. $\S 466 \mathrm{~g}(\mathrm{~d})(4)$.

178. Hines, Nor Any Drop to Drink, 52 Iowa L. Rev. 799, 855-56 (1967).

179. 33 U.S.C. $\& 466 \mathrm{~g}(\mathrm{f})(1)$ (Supp. V, 1970).

180. Id. § $466 \mathrm{~g}(\mathrm{f})(1)$.

181. Id. 
Failing abatement, as a last resort, the Administrator may request the attorney general to bring suit if pollution of waters is endangering the health and welfare of persons in a state other than that in which the objectionable discharge originates, ${ }^{182}$ and with the consent of the governor, in the case of injury and violation occurring within the same state. ${ }^{183}$ The court, in reaching a decision, is to view the evidence, "giving due consideration to the practicability and to the physical and economic feasibility"184 of securing abatement of any pollution proved.

Thus far, the philosophy of administrative persuasion rather than judicial force has prevailed. One chairman of an enforcement committee has written:

In my opening statement, I frequently quote from a Umited States Supreme Court opinion of $1921^{[188]}$ [in which] [t]he Court pointed the unsuitability of court action for settling disputes involving large concentrations of population and industry, the solution to which required complicated technical judgment, mutual concessions, and detailed plans of action. ${ }^{186}$

The accomplishinent, in his opinion, of the Water Quality Act of 1965 may be measured by the percentage of cases disposed of by governmental cooperation or, conversely, by the percentage of cases that do not require court action. ${ }^{\mathbf{1 8 7}}$ By that measure, the Water Quality Act has been highly successful; even though the conference procedure is but the first step in the enforcement of the Act, the overwhelming majority of actions have proceeded no further. ${ }^{188}$

Others reject this claim of success, contending that the Water Quality Act is imcapable of dealing effectively with the problem of water pollution. ${ }^{189}$ The major weaknesses are the uncertainty of the fed-

182. Id. $\$ 466(\mathrm{~g})(1)$.

183. Id. $\$ 466(\mathrm{~g})(2)$.

184. Id. \& $466(\mathrm{~h})$.

185. New York v. New Jersey and Passaic Valley Sewerage Comm'rs, 256 U.S. 296, 299-300 (1921).

186. Stein, Regulatory Aspects of Federal Water Pollution Control, 45 DeNVER L.J. 267, 277-78 (1968).

187. Id. at 278 .

188. Stein, The Actual Operation of the Federal Water Pollution Control Administration, 3 NATURAL RES. LAW 41 (1970). "Since 1956, enforceinent authority to abate pollution has been invoked in 46 separate situations. The conference stage has proven successful in that it has been necessary to proceed to the public hearing in only four cases and to court action only a single time." Id. at 46 . Mr. Stein feels that the record is even more impressive in that approximately three-fourths of the States have been parties to the actions which have iuvolved more than 1,250 inunicipalities, annong them the largest population centers in the country, and some of the nation's biggest industries.

189. Barry characterizes the development of the FWPCA as a "story of delayed and inadequate response to the increasing problems of water pollution." Barry, supra note 18 , at 1104 . 
eral and state roles under the Act and its lengthy procedure which is unsuited to handling emergency situations. Moreover, the responsibility of the judiciary is not satisfactorily defined. The court's obligation to consider the practicability and the physical and economic feasibility of abatement and its jurisdiction to enter judgments and orders according to the requireinents of the "public interest and the equities of the case"190 sound suspiciously like a reasonable use standard. However, the court will have an exhaustive adininistrative inquiry and opinion to draw on in rendering judgment.

\section{III}

RELATIONSHIP: THE REFUSE ACT AND THE WATER QUALITY ACT OF 1965

The relationship between the Refuse Act of 1899 and the Water Quality Act of 1965 is as yet undefined. It appears that the Refuse Act will be enforced quite differently than in the past 71 years. The Federal Water Pollution Control Act, as amended, states expressly that its provisions do not affect or impair the provisions of section 13 of the Rivers and Harbors Act of 1899.191 A federal district court ${ }^{192}$ has held that section 13 is not superseded by the Water Quality Act, rejecting the view that the more recent statute would become meaningless if one arm of the federal government could commence criminal proceedings and get a conviction while the "violator" is in comphance with modern, up-to-date standards for water pollution control set by another arm of the federal government. ${ }^{193}$ Taken literally, section 13 prohibits all discharges unless a permit has been secured from the Army Corps of Engmeers, but the question of what the standards for such a perinit will be remains. Recent developinents, including the concern of administrators under both the Acts for the quality of the effluent ${ }^{194}$ and the reliance of the proposed regulations on the water quality standards, ${ }^{195}$ lead to the conclusion that the criteria for permits under the Refuse Act will be very similar to those required for compliance with the Water Quality Act.

The Justice Department, however, does not currently view the administrative powers of the Army Corps of Engineers as an additional ineans of enforcing the Water Quality Act. Originally, the department's informally stated policy was "to fit [the Refuse Act] into the regulatory scheme devised by Congress to combat pollution most effectively and

190. 33 U.S.C. $\$ 466 \mathrm{~g}$ (h) (Supp. V, 1970).

191. Water Quahity Improvement Act of 1970 , Pub. L. No. 91-224, $\$ 102,84$ Stat. 91 (to be codified as 33 U.S.C. $\$ 1174$ ).

192. United States v. Interlake Steel Corp., 297 F. Supp. 912 (N.D. Ill. 1969).

193. Id.

194. Compare text accompanying notes 75 and 169 supra.

195. See text accompanying notes $70 \& 74$ supra. 
efficiently ...." Enforcement was to be a matter of "prosecutive judgment" and "it would be patently poor prosecutive judgment . . . to bring . . . action under the Refuse Act where such enforcement activity would have a disruptive or devitalizing effect upon programs designed or approved [under the Water Quality Act]. . ."108 Moreover, the Justice Department planned to seek imjunctions agamst persons discharging matter into navigable rivers without a permit where the discharge was "of a contmuing nature, and where the imjunction proceeding would not disrupt, or be inconsistent with, such administrative proceedings as the Department of the Interior may be conducting under the Federal Water Pollution Control Act. . . ."107 Less than a month after the formulation of these objectives, the Justice Department issued official guidelines for hitigation under the Refuse Act. ${ }^{108}$ Considerably more conservative than the originally stated policy, the guidelines allow use of the Refuse Act but rarely as a supplement to the Water Quality Act. United States Attorneys may bring actions against the "occasional or recalcitrant polluter;" they may use the act to "punish or prevent significant discharges, which are either accidental or infrequent, but which are not of a continuing nature resulting from the ordinary operations of a manufacturing plant."100 This more narrow approach severely limits the usefulness of the Refuse Act. It suggests that very few actions will be instituted under it against polluters even though they are violating the quality standards set under the Water Quality Act. Although the Department of the Interior has initiated action agaimst mercury violators under the Refuse Act, it has a limited legal staff. ${ }^{200}$ Thus, it is improbable that it will make significantly greater use of the Act than the Justice Department will, and it is too early to tell what the response of the Environmental Protection Agency will be.

The Justice Department guidelines ignore several potential uses of the Act. First, the enjoining of discharges may be essential in emergencies. In those situations the Refuse Act would be a useful expedient. Crises will arise as testing for heavy metals and other potentially poisonous substances in industrial discharges contimues. One major difficulty, however, will be defining emergency. Perhaps the criteria should be those applicable to specific situations, verified by reliable scientific

196. Letter from Shiro Kashiwa, Assistant Attorney General, June 2, 1970, reprinted in ENVIR. REP.-CURRENT, supra note 5, at 158.

197. Id.

198. Justice Department Guidelines for Litigation under the Refuse Act, ENVIR. REP.-CURRENT, 288

199. Id. (emphasis added).

200. Assistant Interior Secretary Carl L. Klein stated that the Department has neither the capability nor the personnel needed to initiate action under the Refuse Act to enjoin discharge of lead and arsenic. Action against mercury polluters has held up work in the other areas of the departinent, but was justified by the seriousness of the threat. Id. at 384. 
data concerning the amount of the given toxic element that the human or other organism can absorb without harm and the amount of that deleterious substance that actually enters the food chain. If such findings dictate immediate action, the Refuse Act could then be used to enjom discharge of the material. Or, emergency may refer to the general condition of the water supply. If it is true that the United States will be using its waters to capacity by 1980, the nation may be in a state of emergency right now, necessitating utilization of all instruments for pollution control.

The second overlooked use of the Refuse Act might be to operate in the interim while the question of the authority of the Secretary to set effluent standards under the Water Quality Act is being resolved under the protracted procedure outlined in the statute. Since the Refuse Act specifically deals with actual discharge rather than overall stream standards, it could be used effectively agamst violators of the disputed criteria.

Finally, since the procedure for establishment of federal standards under the Water Quality Act apphes only to interstate waters, the Refuse Act may be used to enforce standards in unprotected navigable intrastate waters.

\section{CONCLUSION}

An adequate legislative scheme to control water pollution would combine strict standards with an efficient enforcement procedure. The Water Quality Act does not; it fails to apply sufficient pressure on industry to devise new ways of disposing or reusing wastes. The simplicity of the Refuse Act's enforcenent procedure, in contrast, offers muscle, but it ignores the coinplexities involved in pollution control. In soine cases, there may not be reliable measuring techniques, the teclinology necessary for an evironmentally sound disposal of industrial pollutants, or money to einploy existing knowledge. An injunction against discharge, therefore, inay inean the closing of a plant or, perhaps, the temporary demise of an entire industry. Such an abrupt cure may be as harmful as the disease. If, however, the Refuse Act is integrated into the scheine provided by the Water Quality Act, the faults of both statutes are partially ameliorated. Use of the Refuse Act in cases of emergency and of violation of effluent standards puts teeth into the enforceinent provisions of the Water Quality Act; in the case of intrastate navigable waters, the Refuse Act extends the scope of the modern legislation. On the other hand, use of the water quality standards in actions under the 1899 Act rehieves the court of the responsibility of dealing with scientific inatters in which it inay have hittle competence. This integrated use of the two statutes could help restore the nation's nost valuable resource.

Diane D. Eames 